\author{
Malgorzata Kosala \\ Agnieszka Pichur \\ Katedra Przedsiębiorczości i Innowacji \\ Uniwersytet Ekonomiczny w Krakowie
}

\title{
Analiza działań przedsiębiorczych i postrzeganie prowadzenia dzialalności gospodarczej przez młode pokolenie - wybrane aspekty
}

W procesie budowy gospodarki opartej na wiedzy dużą rolę ma podejmowanie działań m.in. w zakresie liberalizacji rynków, innowacyjności i przedsiębiorczości. Społeczeństwo przedsiębiorcze jest podstawą budowania nowoczesnej, wysoko konkurencyjnej gospodarki. Kształtowanie społeczeństwa przedsiębiorczego prowadzi do sytuacji, w której skłonność do zakładania i prowadzenia działalności gospodarczej dotyczy znacznej części społeczeństwa i każdej z grup społecznych, a nie tylko wybranych, nielicznych jednostek. W kształtowaniu działań przedsiębiorczych szczególnego znaczenia nabiera edukacja w dziedzinie przedsiębiorczości ludzi młodych. Jej celem jest m.in. kształtowanie świadomości, że działalność gospodarcza jest również ścieżką rozwoju zawodowego.

Zwrócenie szczególnej uwagi na świadome profilowanie postaw przedsiębiorczych owocuje w wielu obszarach życia jednostki. Korzyści osiagane są zarówno na polu zawodowym (np. aktywne kształtowanie kariery zawodowej), jak i prywatnym (np. efektywniejsze wykorzystywanie, lokowanie zgromadzonych zasobów finansowych czy czasu). W 1982 r. Albert Shapero stwierdził, że: ,przedsiębiorcy nie rodzą się, tylko się nimi stają (...) odkryte cechy wyróżniające przedsiębiorców od innych nie są określone genetycznie lub utrwalone na zawsze we wczesnym dzieciństwie. Nabiera się ich dzięki doświadczeniom. Są one szczęśliwie wpajane w trakcie edukacji (...)"(Piasecki 1997).

\section{Cel i realizacja badań}

Słowo „przedsiębiorczość” coraz częściej widać na plakatach, ulotkach informacyjnych dotyczących kursów i szkoleń skierowanych do różnych grup społecznych i zawodowych, współfinansowanych także ze środków Unii Europejskiej. Przedsiębiorczość stała się popularnym hasłem w kampaniach wyborczych polityków. Przedsiębiorczość od kilku lat jest jednak przede wszystkim zagadnieniem, z którym oswajają się uczniowie polskich gimnazjów; zagadnieniem, które zgłębiają studenci uczelni państwowych i prywatnych. Zaobserwowane medialne, polityczne i edukacyjne znaczenie przedsiębiorczości czy nawet moda na przedsiębiorczość stały się motywacją do badań nad postrzeganiem prowadzenia działalności gospodarczej przez przedstawicieli młodego pokolenia. Prezentowane w niniejszym artykule wyniki badań są częścią projektu badawczego nt. postaw przedsiębiorczych studentów, realizowanego na Uniwersytecie Ekonomicznym na kierunku ekonomia ${ }^{1}$.

${ }^{1}$ Część wyników badań projektu badawczego opublikowano w artykule: J. Targalski, M. Kosała, A. Pichur 2007. 
Badania sondażowe postaw przedsiębiorczych studentów były realizowane od grudnia $2006 \mathrm{r}$. do stycznia 2007 r. Ankieta badawcza została skierowana do studentów trzeciego roku kierunku ekonomia. Ankietowani studenci w semestrze zimowym roku akademickiego 2006/2007 byli słuchaczami wykładu „Podstawy przedsiębiorczości” i uczestniczyli w ćwiczeniach z tego przedmiotu. Celem badań było ukazanie motywacji studentów do podejmowania działalności gospodarczej, ustalenie, jakie mają doświadczenia i plany związane z karierą zawodową, ale również uzyskanie odpowiedzi na pytanie, jak duża jest grupa osób, które założenie działalności gospodarczej traktują jako ścieżkę kariery zawodowej. Zawarte w niniejszym artykule analizy prezentują część wyników projektu badawczego na Uniwersytecie Ekonomicznym w Krakowie. Badaniem objęto blisko 300 przyszłych studentów kierunku ekonomia. Na ankietę odpowiedziały 222 osoby. Po sprawdzeniu poprawności wypełnienia ankiet, do analizy zakwalifikowano 216 arkuszy z odpowiedziami.

Tab. 1. Ankietowani - wiek, miejsce zamieszkania

\begin{tabular}{|l|r|}
\hline \multicolumn{1}{|c|}{ Wiek } & Liczba osób \\
\hline 21 & 145 \\
22 & 53 \\
\hline 23 & 12 \\
\hline 24 & 1 \\
\hline 20 & 5 \\
\hline Wielkość miejscowości pochodzenia & Liczba osób \\
\hline miasto ponad 500 tys. & 31 \\
\hline miasto 200-500 tys. & 38 \\
\hline miasto 100-200 tys. & 12 \\
\hline miasto 20-100 tys. & 71 \\
\hline miasto poniżej 20 tys. & 21 \\
\hline wieś & 42 \\
\hline Brak danych & 1 \\
\hline
\end{tabular}

Źródło: J. Targalski, M. Kosała, A. Pichur 2007.

Na pytania ankiety poprawnie odpowiedziało 216 osób. Większość to studenci w wieku 21 lat (145 osób; tab. 1). Studenci byli najczęściej absolwentami liceum ogólnokształcącego (213 osób), 3 osoby ukończyły technikum (handlowe i ekonomiczne). Spośród 216 studentów kierunku ekonomia, 23 osoby poinformowały, że studiują równolegle na innych kierunkach: 9 osób - na Akademii Ekonomicznej, pozostałe 14 osób - na innych uczelniach. Ankietowani pochodzili na ogół ze średniej wielkości miast, liczących 20-100 tys. mieszkańców.

\section{Postawa przedsiębiorcza młodego pokolenia}

Studentów poproszono o odpowiedź na pytanie: czy rozważają możliwość założenia działalności gospodarczej? Aż 66\% ankietowanych odpowiedziało pozytywnie, ale $43 \%$ jeszcze nie ma pomysłu, jaka to będzie działalność, a 23\% ma skonkretyzowaną wizję. Jedynie $9 \%$ deklaruje, że nie zamierza zakładać własnej działalności. Pozostała grupa-25\% - nie określiła swych zamierzeń (ryc. 1). Te wyniki sugerują, że prowadzenie własnego przedsiębiorstwa jest poważnie rozważane jako ścieżka kariery zawodowej. 
Ryc. 1. Czy rozważasz prowadzenie własnej działalności gospodarczej?

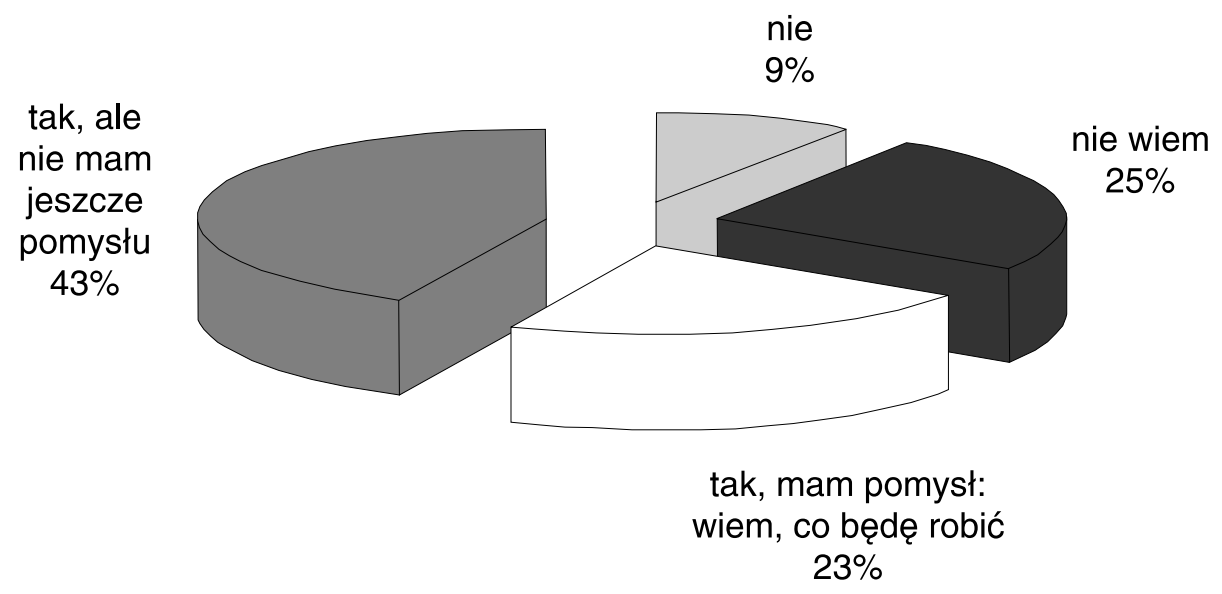

Źródło: J. Targalski, M. Kosała, A. Pichur 2007.

Studentów, którzy rozważają rozpoczęcie własnej działalności gospodarczej (142 osoby - 66\% ankietowanych), zapytano, kiedy planują założenie firmy. Spośród osób, które rozważają założenie własnej firmy, 15\% chce swoje plany realizować jeszcze na studiach. Na chęć założenia własnej firmy w okresie 2-3 lat po ukończeniu edukacji wskazało 32\% respondentów (ryc. 2). Oznacza to, że niemal połowa studentów kierunku ekonomia jest zainteresowana prowadzeniem działalności gospodarczej w bliskiej perspektywie.

Ryc. 2. Kiedy planujesz założenie firmy?

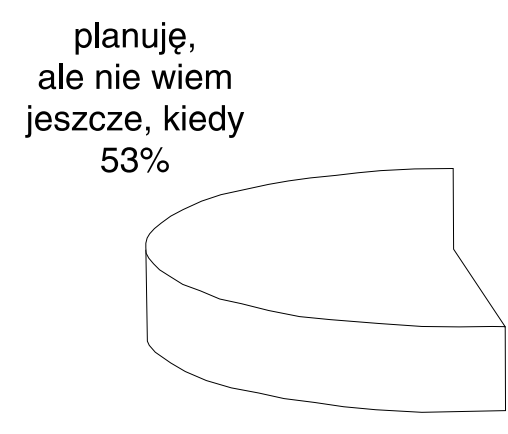

planuje,
ale nie wiem
jeszcze, kiedy

$53 \%$

Źródło: J. Targalski, M. Kosała, A. Pichur 2007.
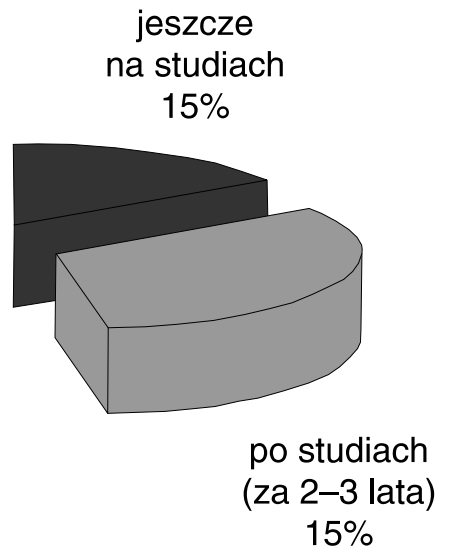

Studentów poproszono o dokonanie samooceny swojej postawy (ryc. 3). Więcej niż połowa badanych $(55,5 \%)$ pozytywnie ocenia swoją postawę w tej kwestii, przy czym $42 \%$ waha się i zaznacza odpowiedź „,raczej tak”, a 13\% prezentuje postawę zdecydowaną. Blisko 40\% uważa, że jeszcze nie może określić się jako osoba przedsiębiorcza, ale z zaznaczeniem, że ciagle się uczy, by taką być. Odsetek osób, które źle oceniły swoją postawę przedsiębiorczą, jest niewielki. 
Ryc. 3. Samoocena postawy przedsiębiorczej

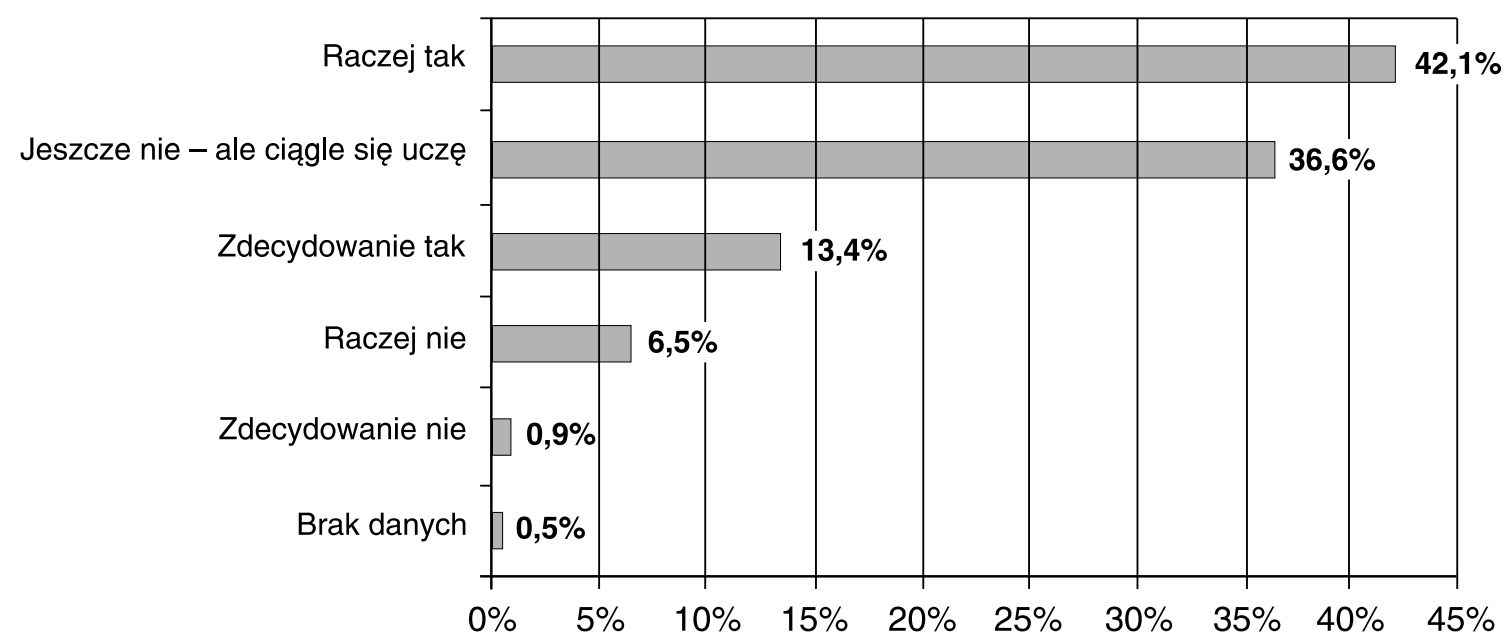

Źródło: J. Targalski, M. Kosała, A. Pichur 2007.

\section{Motywacje i obawy młodego pokolenia potencjalnych przedsiębiorców}

Zdecydowana większość ankietowanych (ponad 90\%) pozytywnie ocenia swoja postawę przedsiębiorczą. Większość studentów rozważa prowadzenie działalności gospodarczej w przyszłości (ryc. 1), dlatego w analizie działań przedsiębiorczych ważne jest poznanie motywacji do założenia firmy czy obaw młodego pokolenia związanych z prowadzeniem własnego przedsiębiorstwa. Czynnikiem, który najmocniej motywuje tych, którzy planują założenie działalności gospodarczej, jest chęć bycia niezależnym (ponad 83\%) oraz oczekiwanie większych korzyści finansowych (60\%). Wyniki ankiety wskazują na to, że studenci nie postrzegają prowadzenia własnej działalności jako sposobu na walkę z bezrobociem - „boję się, że nie znajdę atrakcyjnej pracy" to jedynie 9\% wskazań. Motywacja do zakładania firm wśród studentów nie łączy się z posiadaniem własnego kapitału - jedynie 4\% wskazań (ryc. 4.).

Ryc. 4. Motywacje planujących działalność gospodarczą*

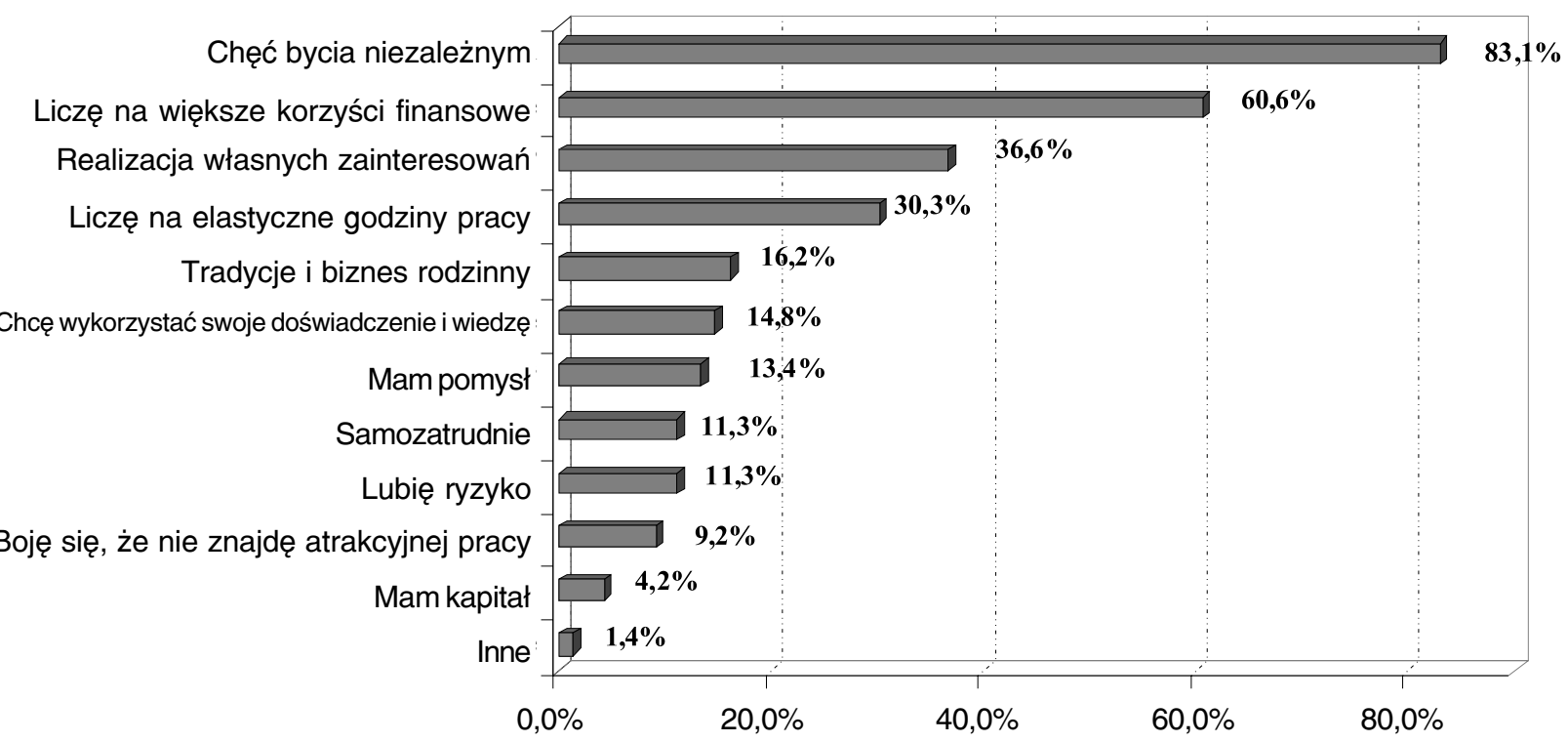

*Wskazanie maksymalnie trzech odpowiedzi.

Źródło: badania autorek. 
Nie wszyscy studenci rozważają prowadzanie w przyszłości własnej firmy. Z pewnością niektórzy z nich mają pewne obawy. Ci właśnie ankietowani zostali poproszeni o wskazanie, co stanowi dla nich najważniejszą przeszkodę w założeniu firmy. Jedynie $10 \%$ odpowiedziało, że nie myśli o przyszłości. To może sugerować, że już zastanawiali się nad karierą przedsiębiorcy. Wśród barier ankietowani w większości wskazują brak pomysłu na własny biznes (51\%). W opiniach studentów ważna jest stabilizacja pracy, która nie łączy się z karierą przedsiębiorcy. Blisko $40 \%$ studentów nie planuje działalności gospodarczej, ponieważ lubi stabilizację w pracy i chce mieć stałe dochody (ryc. 5).

Ryc. 5. Dlaczego nie planujesz założenia własnej firmy?*

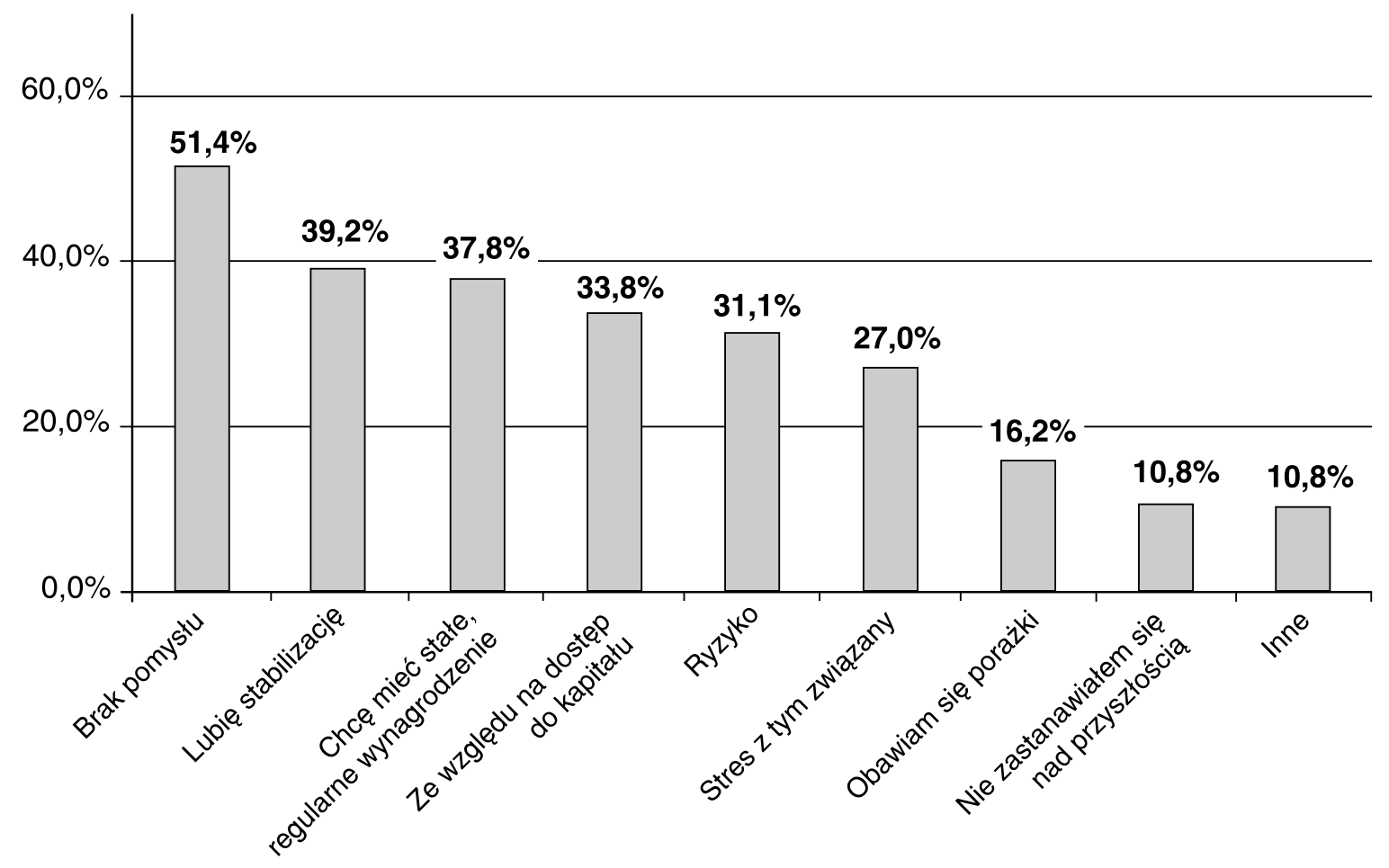

*Wskazanie maksymalnie trzech odpowiedzi.

Źródło: opracowanie autorek.

\section{Przyczyny sukcesu i porażki przedsiębiorców w opinii studentów}

Jedynie niewielka grupa studentów ( $10 \% \mathrm{z}$ tych, którzy nie chcą prowadzić firmy) nie zastanawia się nad swoją zawodową przyszłością. Można zatem wnioskować, że młode pokolenie bacznie przygląda się poczynaniom przedsiębiorców. Studenci zostali zapytani o główne czynniki, które ich zdaniem decydują o przyczynach sukcesów (ryc. 6) i porażek (ryc. 7) przedsiębiorców. 
Ryc. 6. Czynniki sukcesu firmy

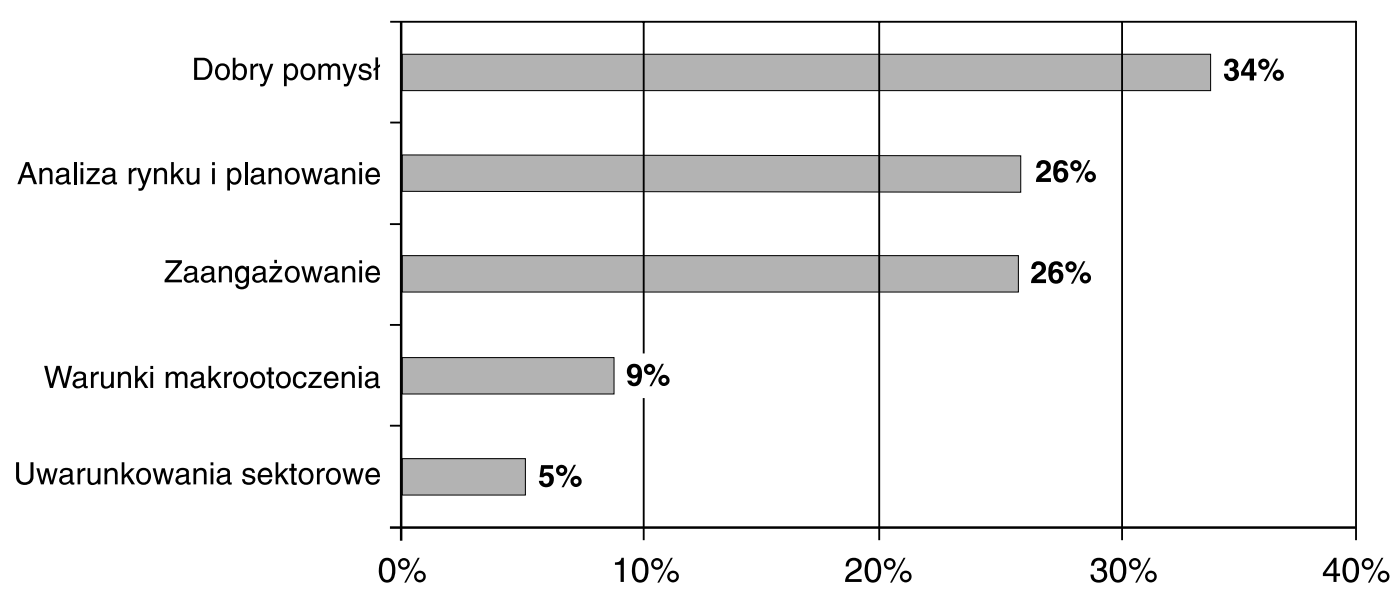

Źródło: opracowanie autorek.

Zwracając uwagę na czynniki przyczyniające się do sukcesu przedsiębiorstwa, 34\% badanych wskazało na rolę dobrze wybranego i opracowanego pomysłu na działalność gospodarczą. W dociekaniach nad przyczynami porażek biznesu ten czynnik również został uznany za najbardziej odpowiedzialny - 19\% odpowiedzi. Potwierdza to pojawiające się w opracowaniach sugestie, że największe prawdopodobieństwo sukcesu mają te firmy, które odpowiadają na niezaspokajane potrzeby lub kreują nowe potrzeby, np. przez nowy produkt, ewentualnie zaspokajają potrzeby już zaspokajane, lecz robią to zdecydowanie lepiej (Targalski 2003). Na kolejnym miejscu znalazły się: analiza rynku i planowanie oraz zaangażowanie przedsiębiorcy. Wskazywał na nie co czwarty badany. Wskazywano również na uwarunkowania makroekonomiczne - 9\% i sektorowe - 5\%. Można wnioskować, że młode pokolenie ma świadomość rangi zarządzania we współczesnych przedsiębiorstwach oraz roli, jaką odgrywa w nim przedsiębiorca, który jest odpowiedzialny (najczęściej) za obszar zarządzania, a więc i jego zaangażowanie w sprawy firmy staje się warunkiem sukcesu.

Ryc. 7. Czynniki niepowodzenia przedsiębiorców

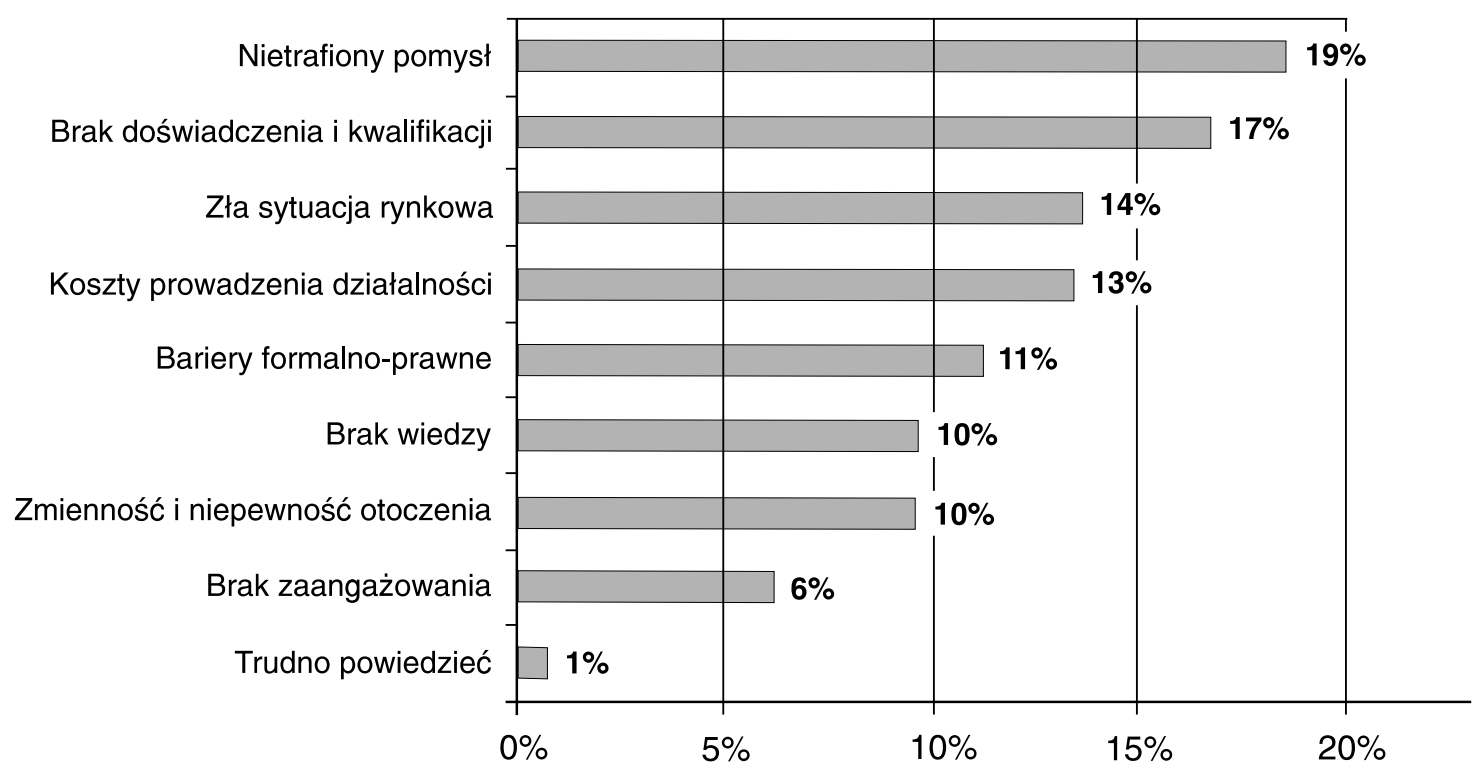

Źródło: opracowanie autorek. 
Co trzeci respondent zwrócił uwagę na uzależnienie sukcesu firmy od pomysłu, a w przypadku niepowodzenia - co piąty. Oznacza to konieczność dogłębnego przemyślenia pomysłu na działalność gospodarczą przedsiębiorstwa w przypadku chęci zakładania firmy, a gdy firma istnieje, pomysł jest raczej wynikiem właściwego zarządzania. Analiza pozostałych czynników niepowodzenia przedsiębiorców na rynku podkreśla znaczenie zarządzania w klasycznym ujęciu. Kolejno jako najistotniejsze wytypowano: brak doświadczenia i kwalifikacji - 17\%, sytuację rynkową $-14 \%$, koszty prowadzenia działalności - 13\%, bariery formalno-prawne $-11 \%$, brak wiedzy, zmienność i niepewność otoczenia - po 10\%, brak zaangażowania $-6 \%$.

\section{Wnioski z badań i podsumowanie}

Wyniki badań pozwalają na określenie poziomu działań przedsiębiorczych, motywacji i postrzegania prowadzenia działalności gospodarczej wśród młodego pokolenia. Wskazują na wysoką skłonność do podejmowania działalności gospodarczej-66\%. Jedynie 9\% deklaruje, że nie zamierza prowadzić własnej działalności. Zdecydowana większość ankietowanych (ponad 90\%) pozytywnie ocenia swoją postawę przedsiębiorczą. Prowadzenie własnego przedsiębiorstwa jest zatem poważnie rozważane jako alternatywna ścieżka kariery zawodowej.

Analiza przyczyn sukcesów i porażek działalności gospodarczej pozwala na stwierdzenie, że młode pokolenie ma świadomość istoty wyróżnienia przedsiębiorstwa na rynku, ale również i rangi zarządzania we współczesnych przedsiębiorstwach.

W momencie zakładania firmy na znaczeniu zyskują: koncepcja, idea, pomysł na przedsiębiorstwo; w przypadku gdy firma istnieje, pomysł nieznacznie traci na rzecz właściwego zarządzania.

Bieżąca analiza rynku, występujących na nim trendów, staje się podstawą planowania działań w intensywnie zmieniającym się otoczeniu. Za obszar zarządzania najczęściej odpowiedzialny jest przedsiębiorca, a więc i jego zaangażowanie w sprawy firmy staje się warunkiem sukcesu. Wyniki badań wskazują na wysoką skłonność do zakładania własnej firmy i wysoki poziom świadomości w zakresie prowadzenia działalności gospodarczej wśród badanych.

\section{Literatura}

1. Piasecki B., 1997, Przedsiębiorczość i mała firma. Teoria i praktyka, Wydawnictwo Uniwersytetu Łódzkiego, Łódź.

2. Targalski J., 2003, Przedsiębiorczość i zarzqdzanie, Wydawnictwo C.H. Beck, Warszawa.

3. Targalski J., Kosała M., Pichur A., 2007, Postawy przedsiębiorcze wśród studentów kierunku ekonomia Akademii Ekonomicznej w Krakowie. Analiza wyników badań [w:] Kształtowanie postaw przedsiębiorczych a edukacja ekonomiczna, P. Wachowiak, M. Dąbrowski, B. Majewski (red.), Fundacja Promocji i Akredytacji Kierunków Ekonomicznych, Warszawa. 


\section{The Way Entrepreneurship is Perceived Among Young Generation and Analysis of Their Entrepreneurial Potential. Data Analysis - Chosen Aspects}

In European Union there has been growing interest in education in the area of entrepreneurship. Programs and agendas present the ideas for training in entrepreneurial attitude for groups of different age. This paper is a contribution to the research on entrepreneurial attitude among young people. The article is based on survey conducted at Cracow University of Economics among the third year students who attended to the academic course of entrepreneurship. The article synthesizes students' opinions, experience and plans for the nearest future. The main interest of the research is whether the young people already consider being entrepreneur as a path for professional career. 